\title{
Histopathological Study of Chick Intestine: Effect of Probiotic and Lead Acetate
}

*Nashaat Gh. Mustafa

Department of Physiology

Biochemistry and Pharmacology

College of Veterinary Medicine

University of Mosul
Enaas Sh. Mustafa

Department of Pathology and

Poultry Diseases

College of Veterinary Medicine

University of Mosul
Sinan Th. Abdullah

College of Environment

University of Mosul

*E-mail: Nashaat_ghalib@yahoo.com

(Received 27 / 11/2013 ; Accepted $30 / 12$ / 2013)

\begin{abstract}
This work was conducted to evaluate the histopathological effects of probiotic (Biomin) and the toxic action of lead acetate on the intestine of one day old forty Ross broiler chicks. The probiotic was used in recommended dose $(1.5 \mathrm{~g} / \mathrm{Kg}$ diet $)$, lead acetate was used in toxic dose of $(320 \mathrm{mg} / \mathrm{kg}$ diet). Results show that the histopathological changes of animal group that was treated with lead acetate in toxic dose for 28 days represent the presence of necrosis at the apex of villi with desquamation and hyperplasia in the epithelium of villi and intestinal gland, while sections of chick intestine that were treated with lead acetate at toxic dose and probiotic at recommended dose for 28 days show the infiltration of lymphocyte in submucosal layer and focal area of coagulative necrosis in muscular layer. The group taken probiotic alone shows mild vascular degeneration when compared with the control group.
\end{abstract}

Keywords: Probiotic, lead acetate, chick, pathological changes.

\section{دراسة مرضية نسجية في أمعاء فروج اللحم: تأثير المعزز الحياتي وخلات الرصاص}

\section{الملغص}

لجري هذا البهث لمعرفة تأثير خلات الرصاص بوصفه من الملوثت البيئية المثائعة والمعزز الحياتي (Biomin) في بعض الصفلت المرضية النسجية في لمعاء فروج اللهم.

لستخدم في هذا البحث 40 فروج لهم من نوع روز وبعمر يوم ولحد وقد لستخدم المعزز الحياتي لوحه بالجرعة (1,5

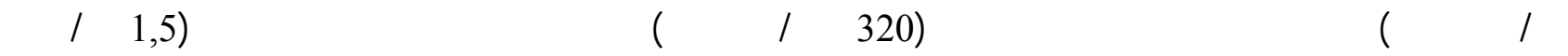
علف) وخلات الرصاص بالجرعة السلمة (320 ملغم/كغم علف) معاً، وكلفت المعلملة لمدة 28 يوماً. لظٔلهرت النتائج أن الحيوانتا المعلملة بخلات الرصاص لوحده بالجرعة للسلمة أدت إلى آحلت مرضية نسجية تمثلت

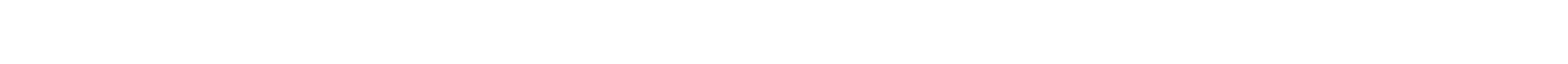

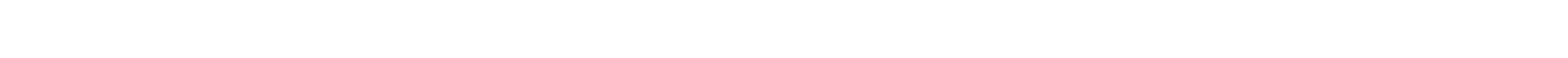

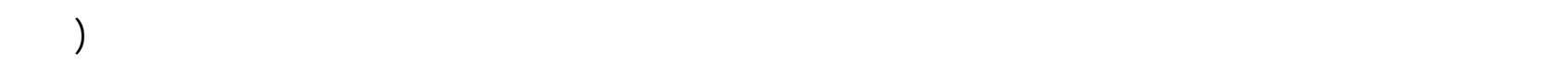

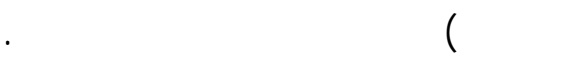

الهاملت الدالة: المعزز الحياتي، خلات الرصاص، أفراخ الدجاج، التغيرات المرضية. 


\section{INTRODUCTION}

Lead $(\mathrm{Pb})$ is considered to be one of the major environmental pollutants and has been incriminated as a cause of accidental poisoning in domestic animals and birds more than any other substances (NRC, 1984), and environmental pollution with lead is a common occurrence in cities and their edges, significant pollution is more likely to occur near smelters or other industrial enterprises, or near major highways where posture is contaminated by exhaust fumes of automobiles (Blood and Rodostits, 1989). However, lead absorption from intestinal tract is variable depending on animal general state, presence of nutrient substances (types and amounts of these substances), duration of exposure, and chemical structure of lead derivatives, which most of lead compounds difficulty solved in water except lead acetate (Mohammad and Al-Khafaji, 2001).

On the other hand, probiotic was defined as a live microbial feed supplement, which beneficially affects the host animal by improving its intestinal balance, it has been used as a substitute of antibiotics that is being used in considerable amounts as growth promoters in broiler products (Ahmad, 2006). However, probiotic acts by different mode of action as: 1. Immune enhancement, it has been reported that probiotics stimulate the immunity of chickens in two ways: a. flora from probiotic migrate throughout the gut wall and multiply to a limited extend or $\mathrm{b}$. antigen released by the dead organisms one absorbed and thus stimulate the immune system (Harenaar and Spanhaak, 1994). 2. Growth stimulation (Baidya et al., 1993) started that probiotics were the most effective growth promoter, and probiotic fed chickens had more weight gain than other groups (Lan et al., 2003). 3. Effect on feed conversion ratio: some studies show that probiotics supplementation in feed of chickens improve the feed convertion ratio (Jagdish and Sen, 1993; Ergun et al., 2000), and finally, it is reported in recent years that probiotics (or some of its compounds) have detoxification action on heavy metals (as lead) (Ibrahim et al., 2006), therefore our goal from the present work is to evaluate the effects of probiotics on lead acetate absorption and toxicity in the intestine of broiler chickens.

\section{MATERIALS AND METHODS}

Experimental animals: One day old forty broiler Ross chickens were obtained from Al-Ameen company for poultry, Mosul, Iraq. Chickens are put in floor cages, with suitable environmental conditions: 12 hours continuous lighting, well humidity, ventilation, and temperature, food and water ad libitum. Experiments were took place in April 2008 in the animal house unit and dept of Physiology, Biochemistry and Pharmacology, College of Veterinary Medicine, University of Mosul.

Probiotic: the probiotic used in thus experiment was BIOMEN IMBO ${ }^{\circledR}$, it was got from local markets, produced by Biomen G.T.I Gmbh Company, Ember AG-Austria, the manufacture recommended dose was $1.5 \mathrm{~g} / \mathrm{kg}$ diet.

Lead that was used was Lead (п) acetate-3-hydrate cryst extra pure $\left(\mathrm{CH}_{3} \mathrm{COO}\right)_{2} .3 \mathrm{H}_{2} \mathrm{O}$. MERCK. E. Merck, Darmstadt. The dose of lead acetate $320 \mathrm{mg} / \mathrm{kg}$ diet was documented by Vengris and Mare (1974) to cause $50 \%$ mortality $\left(\mathrm{LD}_{50}\right)$ in immature chickens, in the present study we used the same dose.

Experimental design: one day old forty broiler chickens were randomly divided into 4 groups ( 8 chickens for each group), and given, from the 1 st day old to 28 day old, the following diets :

1. Group 1 (control group): diet contains essential nutrients optimal to the requirement of chickens (NRC,1984).

2. Group 2: control group diet + lead acetate $320 \mathrm{mg} / \mathrm{kg}$ diet (320 ppm).

3. Group 3: control group diet + probiotic $1.5 \mathrm{~g} / \mathrm{kg}$ diet.

4. Group 4: control group diet + lead acetate $320 \mathrm{mg} / \mathrm{kg}$ diet $(320 \mathrm{ppm})+$ probiotic $1.5 \mathrm{~g} / \mathrm{kg}$ diet.

Each group of chickens weighted $(42 \pm 6) \mathrm{g}$ in the 1 st day of the experimental period. 
Sampling and analysis: the samples taken from chicks intestine and stored in neutral buffer formalin (10\%) and the slides were stained with routines Eosin and Harris hematoxylin for exploring the pathological changes.

\section{RESULTS AND DISCUSSION}

The results show that the histopathological changes of the was animal group that treated with lead acetate in toxic dose of $(320 \mathrm{mg} / \mathrm{kg}$ diet $)$ for 28 days represented by the presence of necrosis at the apex of villi with desquamation and hyperplasia in the epithelium of villi and intestinal glands, (Fig. 1, 2, 3).

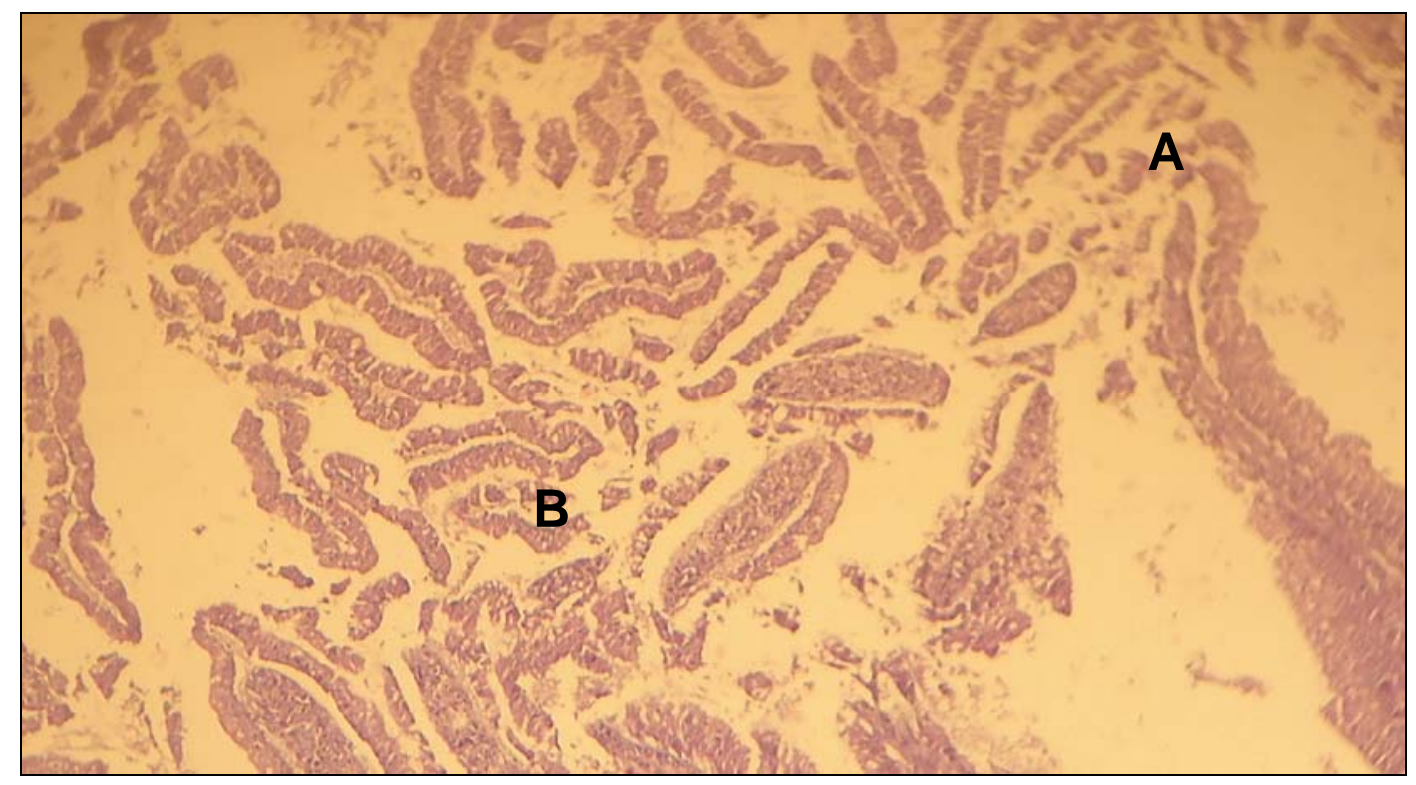

Fig. 1: Histomicrograph of chick intestine treated by lead acetate, show necrosis at apex of villi (A) with desquamation and sloughing in epithelium villi (B). H and $\mathrm{E}$ stain. 240X.

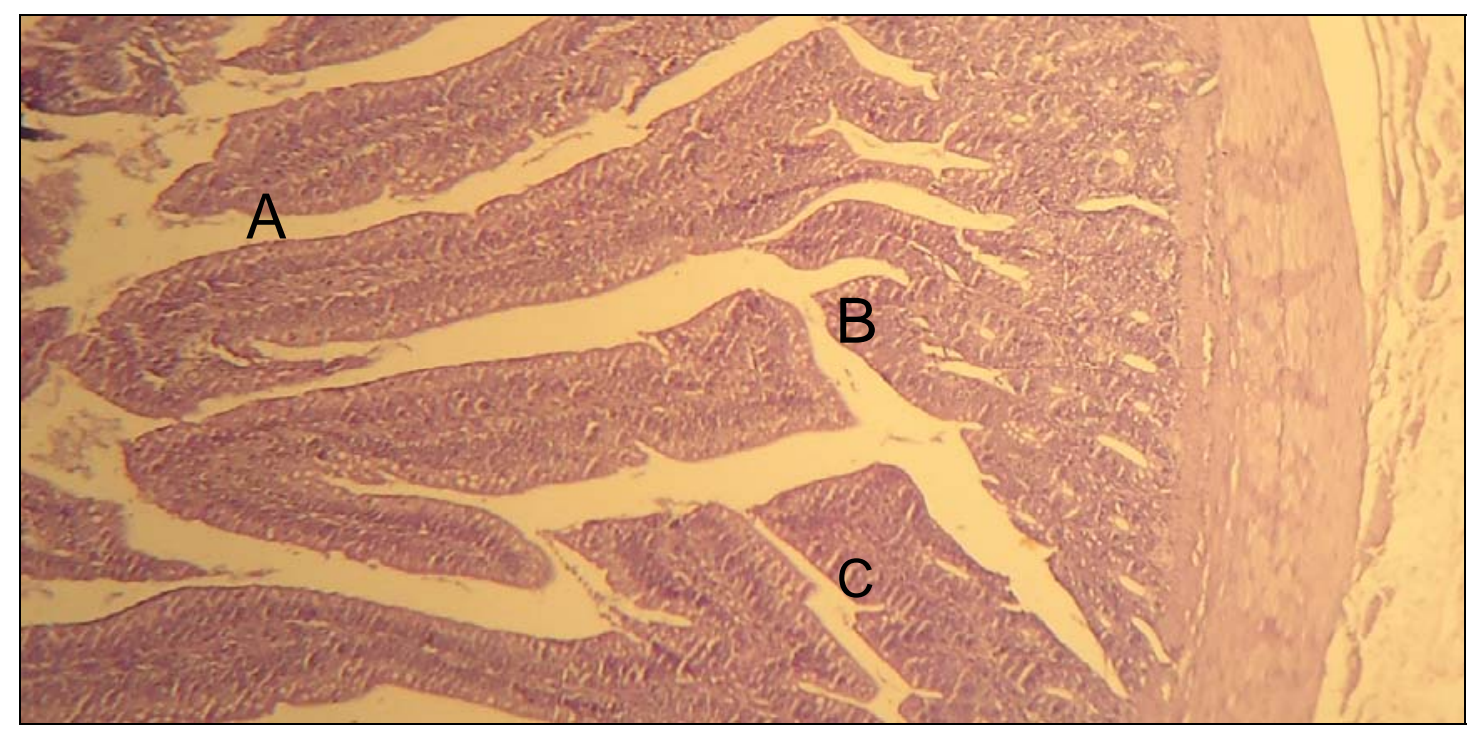

Fig. 2: Histomicrograph of chick intestine treated by lead acetate, show severe hyperplasia in epithelium of villi (A) and intestinal gland (B) with narrowing in gland cavity (C). $\mathrm{H}$ and E stain. 160X. 


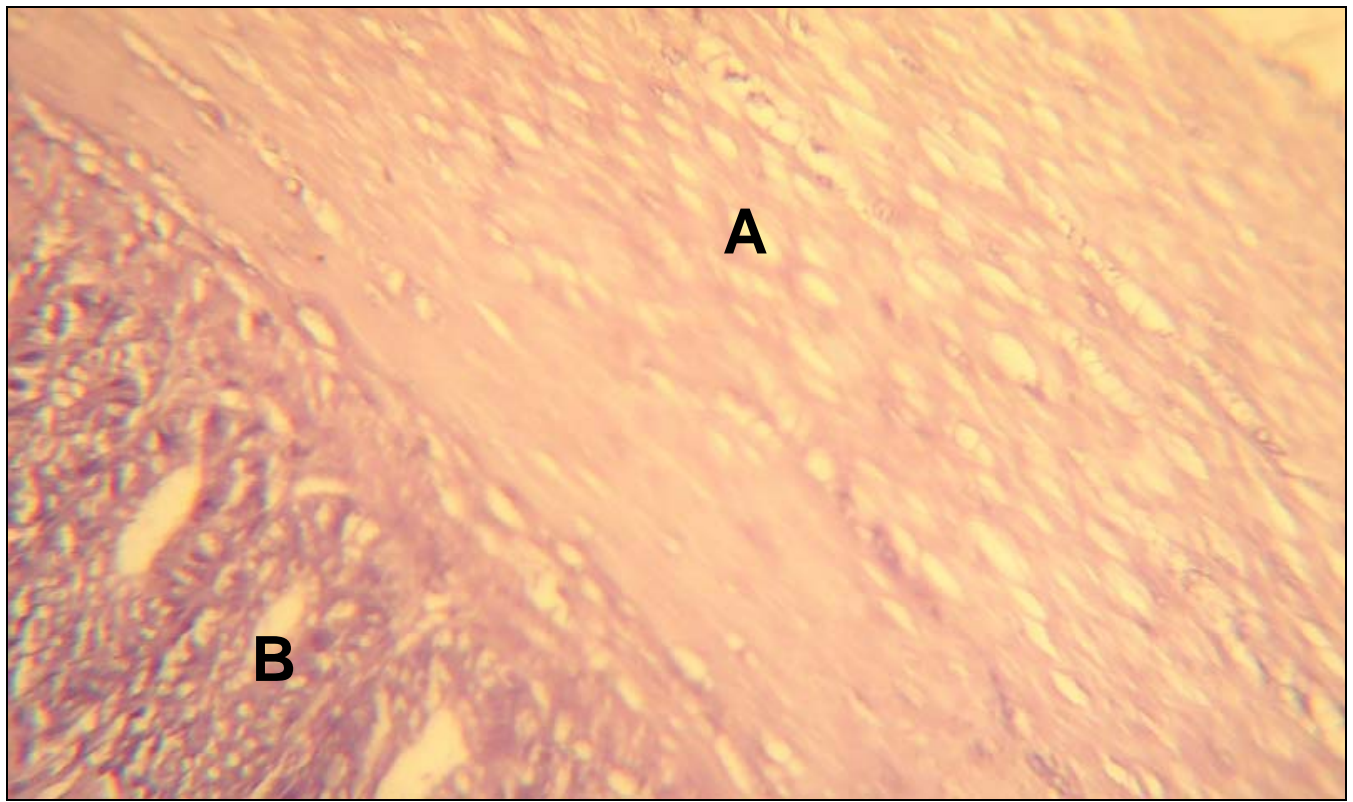

Fig. 3: Histomicrograph of chick intestine treated with lead acetate, show severe fatty changes in muscular layer (A) and vacular degeneration in epithelial cells (B) of intestinal gland. $H$ and $E$ stain. 240X.

While the histological section of animal intestine treated with lead acetate at dose $(320 \mathrm{mg} / \mathrm{kg}$ diet) and probiotic at $(1.5 \mathrm{~g} / \mathrm{kg}$ diet $)$ for 28 days shows dense infiltration of lymphocyte in submucosal layer and focal area of coagulative necrosis in muscular layer (Fig. 4 and 5).

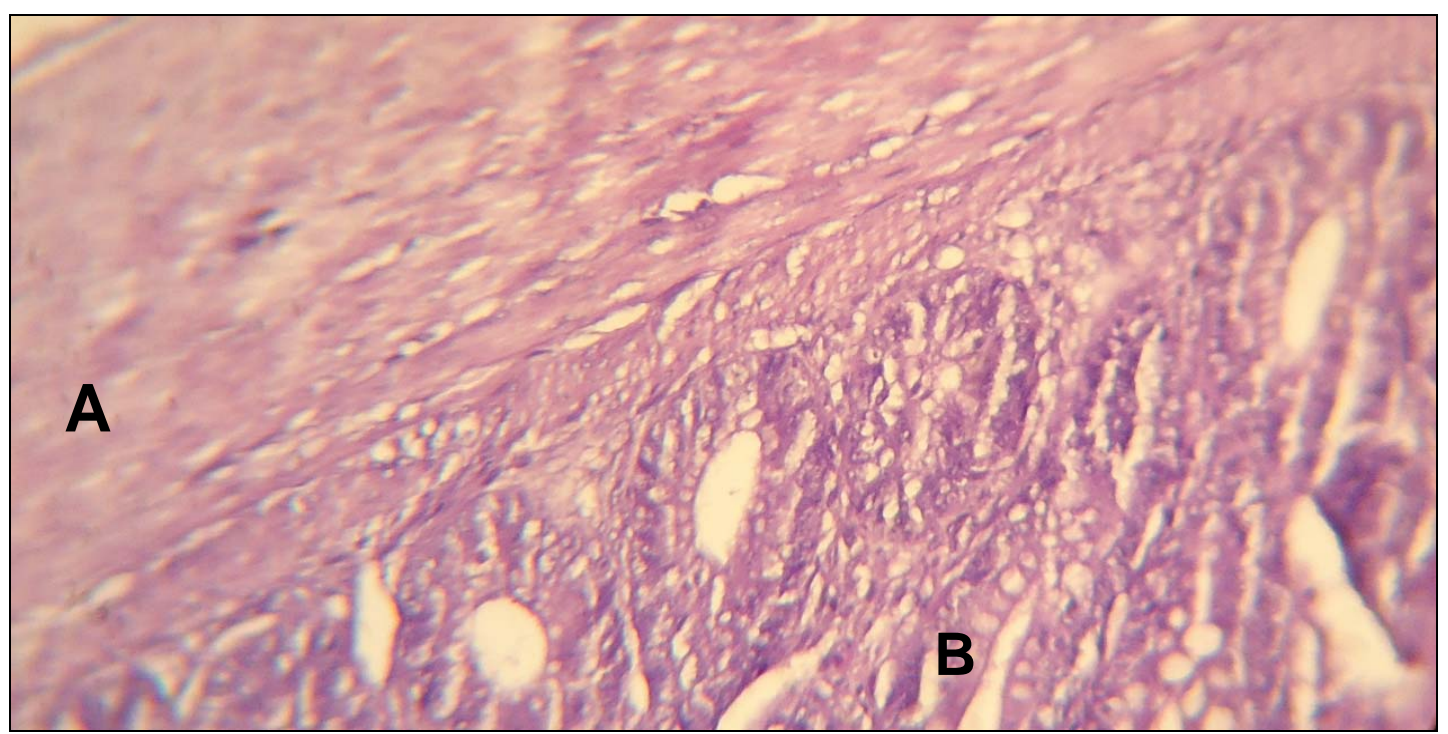

Fig. 4: Histomicrograph of chick intestine treated with lead acetate and probiotics shows focuses of coagulative necrosis in muscular layer (A) and vacular degenerative in intestinal gland epithelia (B). $H$ and $E$ stain. 160X. 


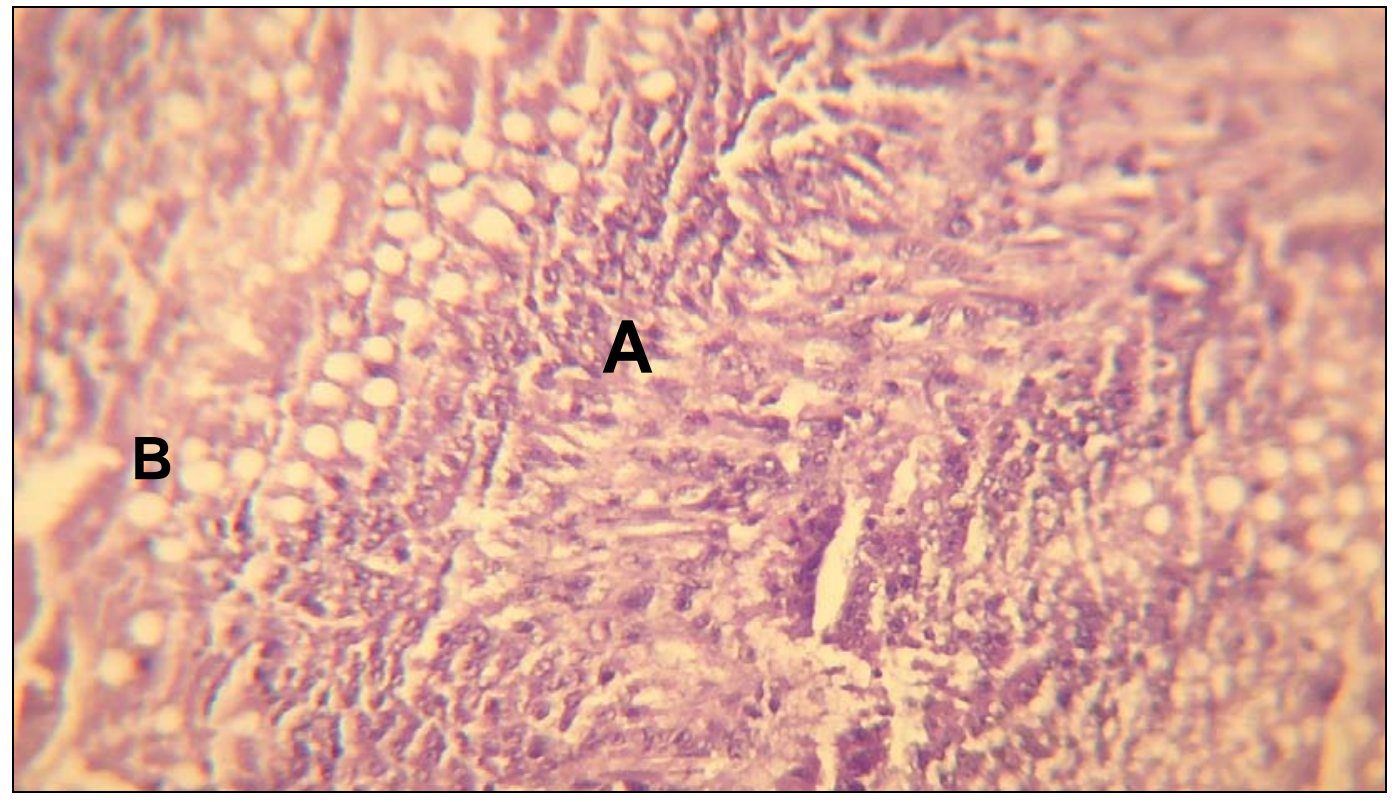

Fig. 5: Histomicrograph of chick intestine treated with lead acetate and probiotic shows a severe infiltration of lymphocytes $(A)$ and vacular degeneration in intestinal gland epithelium (B). H and E stain.160X.

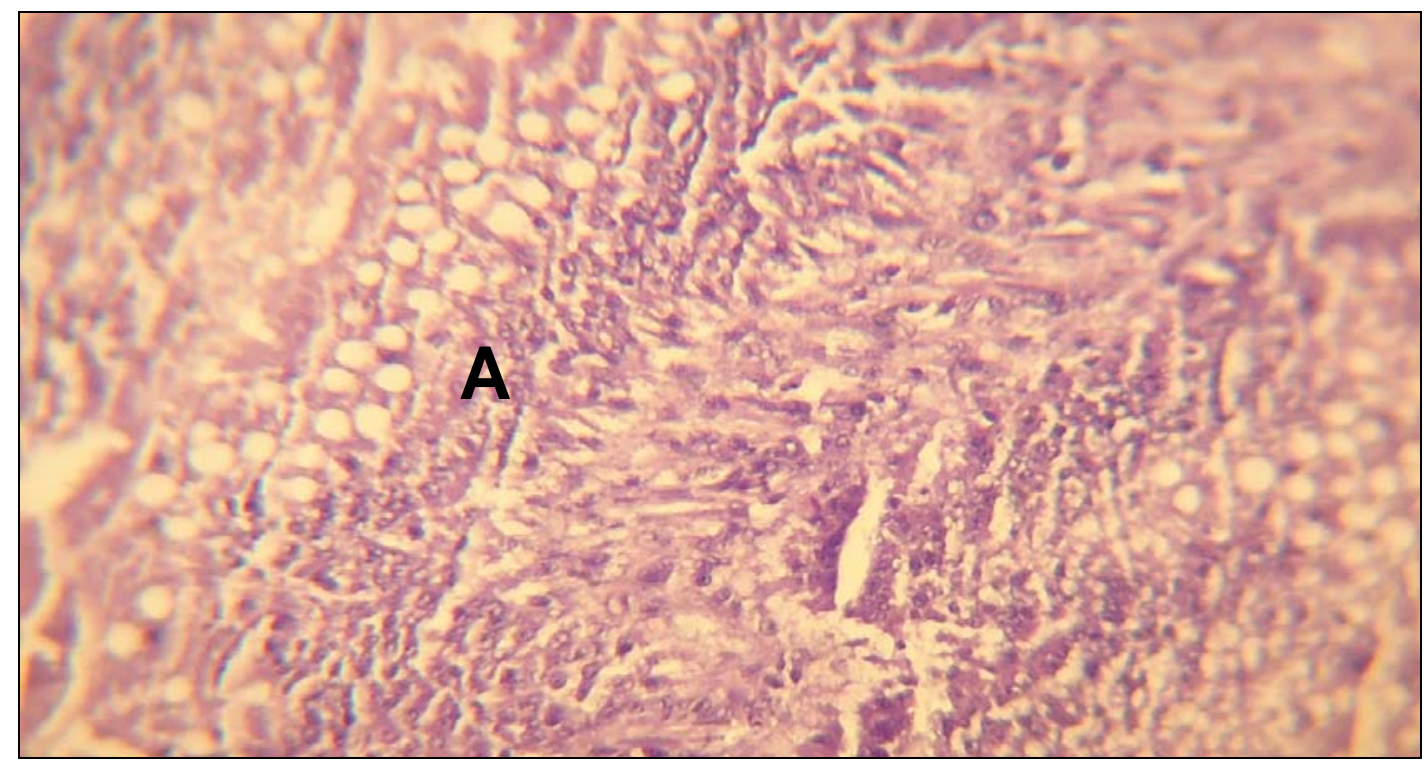

Fig. 6: Histomicrograph of chick intestine treated with lead acetate and probiotic show severe infiltration of lymphocytes (A) in lamina propria. $H$ and $E$ stain. 240X. 


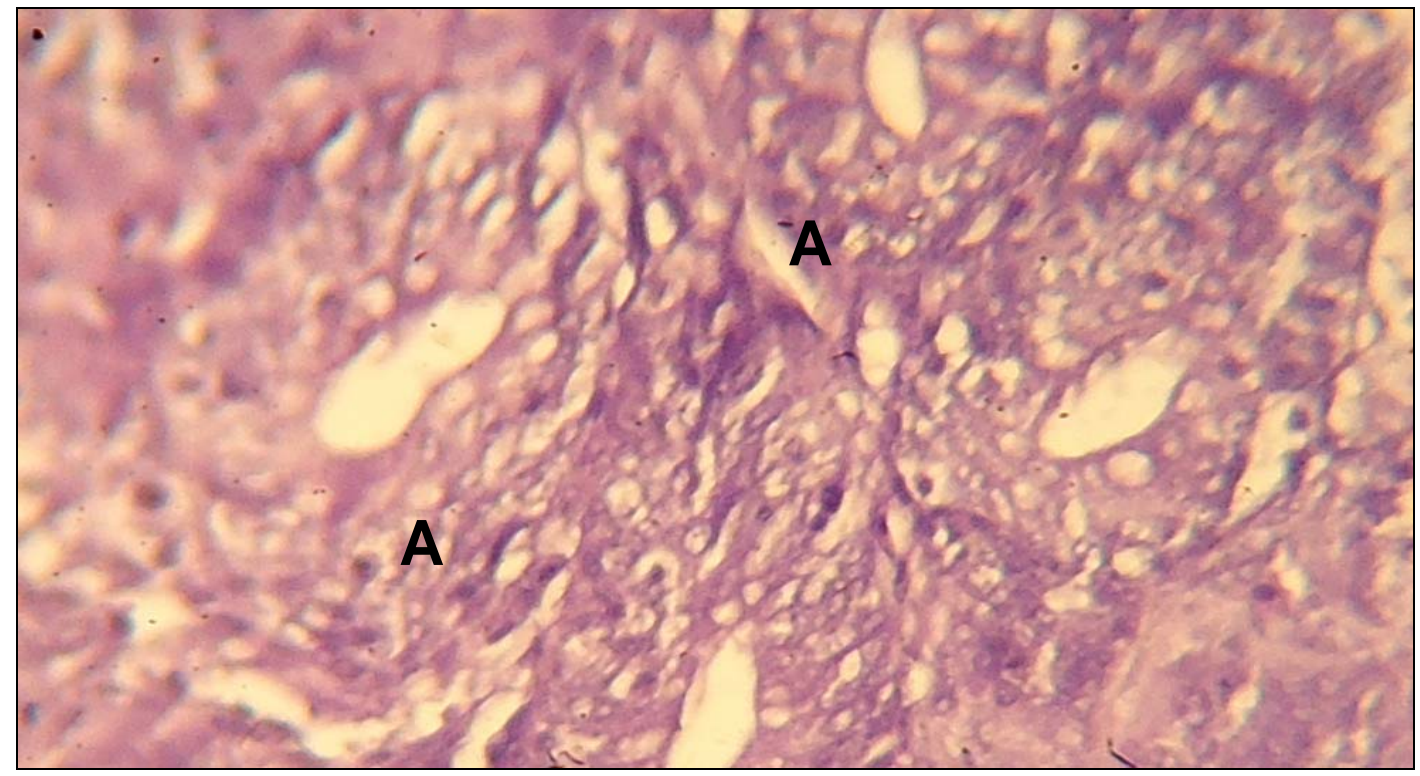

Fig. 7: Histomicrograph of chick intestine treated with probiotic shows mucous degeneration in epithelial cell of intestinal gland. $H$ and $E$ stain. 240X.

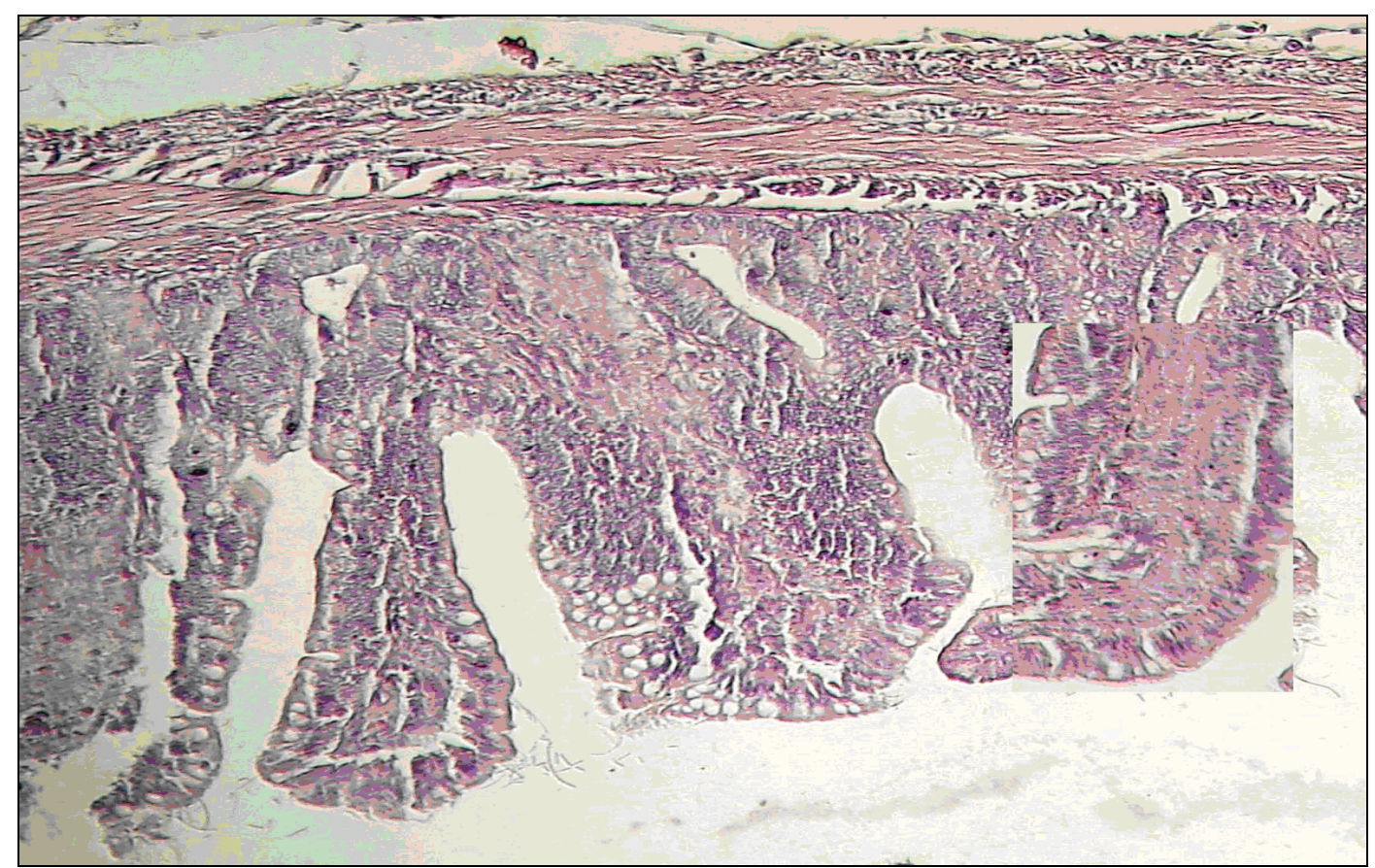

Fig. 8: Histomicrograph of normal chick intestine without treatment (control). $H$ and $E$ stain. 120X.

The group received probiotic alone shows mild vascular degeneration when compared with the control group, (Fig. 6 and 7) when compared with the control group (Fig. 8). Histological study of chick intestine treated with lead acetate $(320 \mathrm{mg} / \mathrm{kg}$ diet $)$ shows necrosis in the apex of intestinal villi with desquamation and severe hyperplasia in villi epithelium and intestinal glands, as well as fatty changes in muscular layer, there is also vacular degeneration in epithelial cells and mild infiltration of lymphocytes in lamina propria (Fig. 1, 2 and 3). These results agree with Ibrahim et al., (2011), who demonstrated that lead acetate causes the destruction of various body organs including intestine, this destructive effect of lead may be due to its ability to inhibit antioxidant enzymes activity as glutathione and superoxide dismutase (SOD), as well as lead has an inducing 
action in releasing free radicals, it also has a harmful effect on certain cell organelles as cell membrane (Patrick, 2006), leading to many dangerous events in the cell including lipid peroxidation (Silbergald and Weaalkes, 2000). Lesions in the intestine of this group are always caused by lead acetate leading to increase mucous protein production by the induction of Goblet cell, and this may be mechanism for the desquamation of cells, this opinion is demonstrated by the presence of hyperplasia in the epithelial cell of intestinal cell.

On the other hand, the pathological changes in the group treated with lead acetate and probiotic, show severe infiltration of lymphocytes with hyperplasia of villi epithelium and intestinal gland with narrowing the intestinal gland partial cilia, and focus on the coagulative necrosis in the muscular layer (Fig. 4 and 5) when compared with the control group (Fig. 8).

Lymphocyte infiltration may be due to immune system induction and enhancement by probiotic (Pelicano et al., 2005).

Finally, the intestine of chick treated with probiotic only, shows mucous degeneration in epithelial cell of villi and intestinal gland, with an increase in the mucous production which may by caused by increasing the activity of intestinal gland, this result agrees with Brahmankar et al., (2011), who show that probiotic in chick diet lend to intestinal gland that enhances dietary absorption.

\section{REFERENCES}

Ahmed, I. (2006). Effect of probiotic on broilers performance. Int. J. Poul. Sci.5(6), 593-597.

Baidya, N.; Mandal, L.; Banerjee, G.C. (1993). Efficiency of feeding antibiotic and probiotic in broilers. J. Vet. Anim. Sci. 24, 120-124.

Blood, D.C.; Rodostits, O.M. (1989). "Veterinary Medicine A Textbook of the Disease of Cattle, Sheep, Pigs, Goat and Horse". 7th ed. Bailliere Tindal Pub. London, pp.1241-1250.

Brahmankar, M.G.; Wagh, S.B.; Kale, D.B.; Joshi, M.V. (2011). Immunotoxicity of lead acetate in broiler birds. Journal home page: http/www.Japhr.iaphp.in.

Ergun, A.; Yalcin, S.; Sacakli, P. (2000). Usage of probiotic and zinc bacteria in broiler rations. Ankara Univ. Vet. Fakul. Dergisi, 47, 271-280.

Harenaar, R.; Spanhaak, S. (1994). Probiotics from an immunological point of view. Curr. Opin. Biotechnol. 5, 320-5.

Ibrahim, F.; Halttunen, T.; Tahvonen, R.; Salminen, S. (2006). Probiotic bacteria as potential detoxification tools: assessing their heavy metal binding isotherms. Can. J. Microbiol. 52 (9), 877-885.

Ibrahim, O.E.; Al-sultan, I.I.; Makkawi, T.A.(2011). Pathological changes induced by chromic exposure to lead acetate and treatment with calcium disodium edetate in broilers. Published on line: 15th December 2011. ISSN, 2231-9123.

Jagdish, P.; Sen, A.K.(1993). Effect of Different Growth promotes on Performance of Broiler. Poult. Advi. 26, 49-51.

Lan, P.T.; Binh, T.L.; Benno, Y.(2003). Impact of two probiotics Lactobacillus strains feeding on fecal Lactobacilli and weight gains in chickens. J. Gen. App. Microbiol. 44, 29-36.

Mohammad, F.K.; Al-Khafaji, N.J. (2001). "Veterinary Toxicology". $1^{\text {st }}$ ed. University of Mosul pub., Iraq. pp.164-172 (in Arabic).

NRC (National Research Council), (1984). "Nutrient Requirements of Poultry". $8^{\text {th }}$ ed., Revised., Washington D.C., pp.11-15.

Patrick, L. (2006). Lead toxicity part II : The role of free radical damage and the use of antioxidants in the pathology and treatment of lead toxicity. Altren. Med. Rev. 11, 114-127.

Pelicano, E.R.; Souza, P.A.; Souza, H.B.A.; Fiquiredo, D.F.; Bolago, M.M.; Carvalho, S.R.; Bardon, V.F. (2005). Intestinal mucosa development in broiler chickens fed natural growth promoters. Braz. J. Poul. Sci., 7(6), 221-229.

Silbergeld, E.K.; Weaalkes, J.M. (2000). Lead as a carcinogen: experimental evidence and mechanism of action. Am. J. Ind. Med., 38, 316-323.

Vengris, V.E.; Mare, C.J. (1974). Lead poisoning in chickens and the effect of lead on Interferon and antibody production. Can. J. Comp. Med., 38, 328-335. 